MORAIS, Lindocastro Nogueira de; LIMA, Jhéssica Luara Alves de. Cooperação internacional em matéria de prova civil. Revista Eletrônica Direito e Política, Programa de Pós-Graduação Stricto Sensu em Ciência Jurídica da UNIVALI, Itajaí, v.11, n.3, $3^{0}$ quadrimestre de 2016. Disponível em: www.univali.br/direitoepolitica - ISSN 1980-7791.

\title{
COOPERAÇÃO INTERNACIONAL EM MATÉRIA DE PROVA CIVIL
}

\author{
INTERNATIONAL COOPERATION IN CIVIL MATTER OF PROOF
}

\section{Lindocastro Nogueira de Morais ${ }^{1}$}

Jhéssica Luara Alves de Lima²

SUMÁRIO: Introdução; 1 . Instrumentos tradicionais de cooperação jurídica internacional; 1.1. Cartas rogatórias; 1.2 . Homologação de sentença estrangeira; 1.3. Pedido de extradição; 1.4. Transferência de pessoas condenadas; 2. Auxílio internacional direto na produção de prova; 3 . Compartilhamento internacional de prova; 3.1. Prova emprestada internacional; 4. Garantias processuais na cooperação internacional; 4.1. Devido processo legal; 4.1.1 contraditório; 4.1.2. Ampla defesa; 4.1.3. Igualdade de partes; considerações finais; referências das fontes citadas.

\section{RESUMO}

O estudo da cooperação internacional em matéria de prova civil não constitui novidade na seara jurídica, todavia adquire importância nos dias atuais. A cooperação jurídica internacional possibilita celeridade e minimiza a burocracia da máquina judiciária dos países. De 1951 a 2007, a Conferência da Haia de Direito Internacional Privado concluiu trinta e nove instrumentos internacionais. Dentre os textos que tiveram maior número de ratificações ou de adesões, salientam-se os que se reportam à cooperação judiciária e administrativa internacional. Dessa forma, importante seu estudo de modo a verificar se essa cooperação tem sido eficaz para a garantia dos direitos conferidos pelos documentos internacionais. Para tanto, o trabalho utiliza-se de pesquisa bibliográfica. A pesquisa constatou que as garantias estão positivadas na legislação e documentos internacionais, todavia, a efetividade destas, depende da real colaboração entre os países, minimizando burocracias, aperfeiçoando os instrumentos de coleta de provas, e observando os direitos processuais e humanos.

Palavras-Chave: Cooperação Jurídica Internacional. Obtenção de Provas. Ajuda Mútua.

\footnotetext{
${ }^{1}$ Doutorando em Direito na Universidade de Coimbra - UC, Mossoró, Rio Grande do Norte, Brasil, Professor de Direito Previdenciário na Universidade do Estado do Rio Grande do Norte - UERN, Advogado, E-mail: lindocastro@hotmail.com

2 Aluna especial do Doutorado Interinstitucional em Direito da Universidade de Brasília - DINTER UNB, Mossoró, Rio Grande do Norte, Brasil, Professora de Direito Civil, Advogada, E-mail: jhessicaluara@hotmail.com
} 
MORAIS, Lindocastro Nogueira de; LIMA, Jhéssica Luara Alves de. Cooperação internacional em matéria de prova civil. Revista Eletrônica Direito e Política, Programa de Pós-Graduação Stricto Sensu em Ciência Jurídica da UNIVALI, Itajaí, v.11, n.3, $3^{0}$ quadrimestre de 2016. Disponível em: www.univali.br/direitoepolitica - ISSN 1980-7791.

\section{ABSTRACT}

The study of international cooperation on civil evidence is not new in the legal harvest, however acquires importance today. International legal cooperation enables speed and minimizes bureaucracy judicial machinery of the country. From 1951 to 2007, the Hague Conference on Private International Law concluded thirty-nine international instruments. Among the texts that had a higher number of ratifications or accessions, the stand out that they relate to legal and international administrative cooperation. Thus, important their study in order to verify that such cooperation has been effective in ensuring the rights conferred by international documents. Therefore, the work makes use of literature. The survey found that the guarantees are positivadas legislation and international documents, however, the effectiveness of these depends on the actual collaboration between countries, reducing bureaucracy, improving the tools for gathering evidence and observing the procedural and human rights.

Keywords: International Legal Cooperation. Evidence. Mutual help.

\section{INTRODUÇÃO}

A cooperação internacional em matéria de prova civil se dá em razão da constante movimentação de pessoas, bens, serviços, informações e capitais entre os países e a necessidade de garantia do devido processo legal em uma investigação processual. Cada dia mais surgem meios que permitem aos países desenvolverem a cooperação recíproca para o exercício de sua atividade jurisdicional. Dessa forma, a cooperação internacional em matéria de prova civil é instrumento que viabiliza a relação mútua entre os Estados, em que um pede a outro que execute decisão sua ou profira decisão própria sobre determinado litígio ${ }^{3}$.

A cooperação internacional em matéria de prova civil objetiva estabelecer uma maior proximidade entre os países para fins de colaboração recíproca. Possui o intuito de eliminar obstáculos decorrentes das incompatibilidades entre os sistemas judiciários e administrativos dos países e, assim, possibilitar o acesso à justiça e as garantias constitucionais e legais em favor do devido processo legal e busca da verdade dos fatos através das provas. ${ }^{4}$ Para viabilizar a cooperação internacional, os países

\footnotetext{
3 MINISTÉRIO DA JUSTIÇA. Cartilha Cooperação Jurídica Internacional em Matéria Civil. 2012. 
MORAIS, Lindocastro Nogueira de; LIMA, Jhéssica Luara Alves de. Cooperação internacional em matéria de prova civil. Revista Eletrônica Direito e Política, Programa de Pós-Graduação Stricto Sensu em Ciência Jurídica da UNIVALI, Itajaí, v.11, n.3, $3^{0}$ quadrimestre de 2016. Disponível em: www.univali.br/direitoepolitica - ISSN 1980-7791.

firmam acordos e tratados internacionais, ${ }^{5}$ bilaterais ou multilaterais. A complexidade dos casos judiciais e administrativos que se apresentam em matéria processual civil, muitas vezes, vão além da jurisdição nacional, fazendo com que os Estados possuam a necessidade na promoção da cooperação internacional.

A soberania de cada país deve ser respeitada. Para tanto, os Estados Partes devem cumprir suas obrigações para com as convenções, tratados e acordos, sempre respeitando os princípios da igualdade soberana e da integridade territorial dos Estados, sem interferir nos assuntos internos dos outros Estados. ${ }^{6}$

A Constituição Federal Brasileira de 1988 contém preceitos relacionados ao procedimento de ingresso, execução e à incorporação dos acordos e tratados internacionais e seus efeitos na ordem jurídica interna (art. 49), sendo o Presidente da República que os assina, ratifica e promulga internamente (art. 84, VIII). O Brasil rege-se nas suas relações internacionais por princípios que devem ser respeitados para a garantia dos direitos positivados na Constituição Federal (art. $\left.4^{\circ}\right)^{7}$.

No mesmo sentido, conforme a Constituição Federal Portuguesa, art. 70, Portugal rege-se nas suas relações internacionais pelos princípios da independência nacional, do respeito aos direitos humanos, dos direitos dos povos, da igualdade entre os Estados, da solução pacífica dos conflitos internacionais, da não ingerência nos assuntos internos dos outros Estados e da cooperação com todos os outros povos para a emancipação e o progresso da humanidade.

A cooperação jurídica internacional vai além de um compromisso moral, passando a se constituir em uma obrigação jurídica fundamental para a harmonia entre as

<http://europa.eu/legislation_summaries/justice_freedom_security/judicial_cooperation _in_civil_matters/index_pt.htm>. Acesso em: 28 abr. $201 \overline{5}$.

${ }^{5}$ Os tratados e acordos internacionais são instrumentos de relações jurídicas antigos, tão antigos quanto às relações entre as nações, constituindo-se exercício de soberania dos países. YODA, A. J. $V$. Disponível em: <http://www.planalto.gov.br/ccivil_03/revista/Rev_75/artigos/PDF/AnaVeneroso__Rev75.pdf>. Acesso em: 28 abr. 2015.

6 Redação semelhante tem o Decreto no 5.015, de 12 de março de 2004, que Promulga a Convenção das Nações Unidas contra o Crime Organizado Transnacional.

7 O Novo Código de Processo Civil (NCPC) brasileiro traça a base principiológica da cooperação internacional e estabelece o Ministério da Justiça como autoridade central, conforme se observa de seu art. 26. 
MORAIS, Lindocastro Nogueira de; LIMA, Jhéssica Luara Alves de. Cooperação internacional em matéria de prova civil. Revista Eletrônica Direito e Política, Programa de Pós-Graduação Stricto Sensu em Ciência Jurídica da UNIVALI, Itajaí, v.11, n.3, 30 quadrimestre de 2016. Disponível em: www.univali.br/direitoepolitica - ISSN 1980-7791.

nações, preservando, no plano internacional, a justiça e a solidariedade, como os valores fundamentais ${ }^{8}$.A cooperação jurídica internacional deve ir além da positivação, visando alcançar a realidade dos sujeitos processuais que dependem de uma medida executada em outro país. Todavia, importante destacar que a diversidade de ordenamentos jurídicos entre os Estados é um empecilho para a efetividade da cooperação mútua internacional, especialmente quanto a obtenção de prova ${ }^{9}$.

Dessa forma, importante estudar a cooperação jurídica internacional em matéria de prova civil, seus instrumentos, auxílio internacional direto na produção de prova, compartilhamento internacional de prova, prova emprestada internacional e garantias processuais na cooperação internacional. O trabalho utiliza como metodologia o estudo bibliográfico e legislativo na busca de fundamentar sobre a cooperação jurídica internacional em matéria de prova civil e sua importância na atualidade.

Assim, o trabalho pretende ser um instrumento viabilizador de novas pesquisas sobre a temática, compartilhando conhecimentos em prol da interação entre os sistemas judiciais dos diversos países.

\section{INSTRUMENTOS TRADICIONAIS DE COOPERAÇÃO JURÍDICA INTERNACIONAL}

O Estado retira o poder da sociedade de exercer a autotutela, mas, como corolário, é obrigado a entregar a esta um sistema jurídico eficaz e dotado de capacidade para se adequar às diversas necessidades da sociedade ${ }^{10}$. Para tanto, existem diversos

8 ARAÚJO, N. de; GAMA JUNIOR, L. Sentenças estrangeiras e cartas rogatórias: novas perspectivas da cooperação internacional. Disponível na Internet: <https://fichasmarra.wordpress. com/2011/01/29/sentencas-estrangeiras-e-cartas-rogatoriasnovas-perspectivas-da-cooperacao-internacional/>. Acesso em 05 jun. 2015.

9 CARVALHO FILHO, A. Obtenção transnacional de prova em matéria civil e comercial: Análise da Convenção de Haia de 1970, da Convenção Interamericana de 1975 e do Regulamento (CE) n.0 1206/2001. Disponível em: <http://www.abdpc.org.br/abdpc/artigos/Obten\%C3\%A7\%C3\%A30\%20transnacional\%20de\%2 Oprova\%20em\%20mat\%C3\%A9ria\%20civil\%20ou\%20comercial\%20-\%20artigo.pdf>. Acesso em: 08 mai. 2015.

10 CAMPOS, P. T. de. Cooperação jurídica internacional: carta rogatória e homologação de sentença estrangeira. In: Âmbito Jurídico, Rio Grande, XVI, n. 113, jun 2013. Disponível em: 
MORAIS, Lindocastro Nogueira de; LIMA, Jhéssica Luara Alves de. Cooperação internacional em matéria de prova civil. Revista Eletrônica Direito e Política, Programa de Pós-Graduação Stricto Sensu em Ciência Jurídica da UNIVALI, Itajaí, v.11, n.3, $3^{0}$ quadrimestre de 2016. Disponível em: www.univali.br/direitoepolitica - ISSN 1980-7791.

instrumentos de cooperação jurídica internacional. Entre eles, os tradicionais são as cartas rogatórias, a homologação de sentença estrangeira, o pedido de extradição e a transferência de pessoas condenadas.

A cooperação jurídica internacional é matéria tratada pela Conferência da Haia, que trouxe a cooperação processual civil como um dos primeiros temas abordados. Essa primeira convenção, datada de 1896, foi sobre processo civil, e quando da retomada dos trabalhos, já como organização internacional, sua primeira normativa também tratava do direito processual, chamada de Convenção sobre Processo Civil. ${ }^{11} \mathrm{~A}$ Convenção relativa à obtenção de provas em matéria civil ou comercial, datada de 18 de março de 1970, é um dos instrumentos fundamentais para a cooperação judicial internacional, todavia, suas bases são fixadas em paradigmas tradicionais, em razão do momento histórico em que foi criada, que impede um maior intercâmbio entre os Estados ${ }^{12}$.

A cooperação internacional em matéria de prova civil se faz necessária considerando que a existência de mudanças no plano tecnológico e político e o crescente aumento no deslocamento de pessoas e bens entre as fronteiras geográficas ${ }^{13}$. Assim, os Estados têm fortalecido o interesse nos instrumentos processuais de cooperação jurídica, e, mais, no desenvolvimento destes para facilitar o acesso à justiça.

Em razão da crescente migração de pessoas, as partes e as provas de um processo judicial podem estar espalhadas por diversas jurisdições, o que requer a cooperação entre os países, pois um Estado deve recorrer a jurisdição de outro Estado para obter determinadas provas. Assim, o que antes talvez fosse visto como uma violação

\footnotetext{
<http://www.ambito-juridico.com.br/site/?n_link=revista_artigos_leitura\&artigo_id=13321>.
} Acesso em: 25 abr. 2015.

${ }^{11}$ ARAÚJO, N.; VARGAS, D. A conferência da Haia de direito internacional privado: reaproximação do Brasil e análise das convenções processuais. Revista de Arbitragem e Mediação, vol.35/2012, p.189, Out/2012, DTR\2012\451121.

12 CARVALHO FILHO, A. Obtenção transnacional de prova em matéria civil e comercial: Análise da Convenção de Haia de 1970, da Convenção Interamericana de 1975 e do Regulamento (CE) n.0 1206/2001. Disponível em: <http://www.abdpc.org.br/abdpc/artigos/Obten\%C3\%A7\%C3\%A30\%20transnacional\%20de\%2 Oprova\%20em\%20mat\%C3\%A9ria\%20civil\%20ou\%20comercial\%20-\%20artigo.pdf>. Acesso em: 08 mai. 2015.

13 MCLEAN, D. International Co-operation in Civil and Criminal Matters. Oxford: Oxford University Press, 2002. 
MORAIS, Lindocastro Nogueira de; LIMA, Jhéssica Luara Alves de. Cooperação internacional em matéria de prova civil. Revista Eletrônica Direito e Política, Programa de Pós-Graduação Stricto Sensu em Ciência Jurídica da UNIVALI, Itajaí, v.11, n.3, 30 quadrimestre de 2016. Disponível em: www.univali.br/direitoepolitica - ISSN 1980-7791.

da soberania dos Estados, atualmente é reconhecido como um meio de para que um Estado soberano resguarde sua Justiça ${ }^{14}$.

O Poder Judiciário exerce o papel de guardião das leis e da Constituição Federal no que toca à cooperação internacional, ao proferir, decisões, por exemplo, quanto aos pedidos de cooperação feitos por meio de carta rogatória, ação de homologação de sentença estrangeira ${ }^{15}$, pedidos de extradição e transferência de pessoas condenadas.

Assim, esses instrumentos tradicionais de cooperação jurídica internacional, devem ser competentes para trazer a colaboração efetiva entre os países em matéria de provas, para fins de resguardar a soberania dos mesmos frentes aos problemas atuais.

\subsection{CARTAS ROGATÓRIAS}

A cooperação jurídica internacional clássica, em um primeiro momento, se dá através do cumprimento de cartas rogatórias, mecanismo consagrado na legislação processual civil de vários países ${ }^{16}$. As cartas rogatórias destinam-se ao cumprimento de diversos atos, tais como os ordinatórios de citação e notificação; os de coleta de prova, conhecidos como instrutórios; bem como os que contêm medidas de caráter restritivo, cujo caráter é executório ${ }^{17}$.

Nos termos do Novo Código de Processo Civil Brasileiro, expedir-se-á carta rogatória, quando dirigida à autoridade judiciária estrangeira (art. 40). Para a prática de atos

14 TOFFOLI DIAS, J. A.; JUNGER CESTARI, V. (Org). Manual de Cooperação Jurídica Internacional e Recuperação de Ativos, em matéria civil. 1.ed. Brasília: ed. Ministério da Justiça, 2008, p.11.

15 TOFFOLI DIAS, J. A.; JUNGER CESTARI, V. (Org). Manual de Cooperação Jurídica Internacional e Recuperação de Ativos, em matéria civil. 1.ed. Brasília: ed. Ministério da Justiça, 2008, p. 16.

16 Nos termos da Conferência da Haia de Direito Internacional Privado: Decreto n. ${ }^{\circ}$ 764/74 de 30 de Dezembro: Convenção sobre a Obtenção de Provas no Estrangeiro em Matéria Civil ou Comercial, a autoridade judiciária de um Estado contratante pode, de harmonia com as disposições da sua legislação, requerer por carta rogatória à autoridade competente de um outro Estado contratante a prática de qualquer ato de instrução ou de quaisquer outros actos judiciários (art. $1^{\circ}$ ).

17 ARAÚJO, N.; VARGAS, D. A conferência da Haia de direito internacional privado: reaproximação do Brasil e análise das convenções processuais. Revista de Arbitragem e Mediação, vol.35/2012, p.189, Out/2012, DTR\2012\451121. 
MORAIS, Lindocastro Nogueira de; LIMA, Jhéssica Luara Alves de. Cooperação internacional em matéria de prova civil. Revista Eletrônica Direito e Política, Programa de Pós-Graduação Stricto Sensu em Ciência Jurídica da UNIVALI, Itajaí, v.11, n.3, 30 quadrimestre de 2016. Disponível em: www.univali.br/direitoepolitica - ISSN 1980-7791.

processuais que exijam intervenção dos serviços judiciários, o Código de Processo Civil Português, na mesma linha, solicita-os a outras autoridades por carta rogatória (art. 172).

No caso do Brasil, o atual momento histórico-processual é de críticas ao Poder Judiciário $^{18}$ em razão da morosidade, razão pela qual alguns instrumentos processuais tem se atualizado para fins de acompanhar a evolução das tecnologias da sociedade atual. Nesse sentido, para facilitar o procedimento, a carta rogatória pode ser expedida via eletrônica (art. 232, NCPC).

As cartas rogatórias são meios de interação entre os países em matéria processual civil, considerando-se inacessível, de acordo com o Novo Código de Processo Civil Brasileiro, o país que recusar o cumprimento desta (art. 256, III, §10). As cartas rogatórias se mostram importantes instrumentos processuais, pois muitas vezes surge a necessidade de se realizarem certos atos que se encontram fora dos limites territoriais de competência dos juízes. Assim sendo, necessária a cooperação jurídica internacional. Sem esta cooperação é possível que os atos processuais não possam ser praticados, ou, ainda, se praticado, estará sujeito à pena de nulidade ${ }^{19}$.

A carta rogatória se faz necessária porque o poder jurisdicional, só pode ser exercido dentro do território nacional ${ }^{20}$. Assim, para adentrar em país diverso, necessária a cooperação jurídica entre os países ${ }^{21}$. Dessa forma, o papel da carta rogatória na cooperação internacional se dá quando se fizer necessário acionar a autoridade judiciária estrangeira para a prática de diligências para o auxílio da instrução processual, seja para a busca de provas, ou mesmo para efetuar termos processuais

${ }^{18}$ CAMPOS, P. T. de. Cooperação jurídica internacional: carta rogatória e homologação de sentença estrangeira. In: Âmbito Jurídico, Rio Grande, XVI, n. 113, jun 2013. Disponível em: <http://www.ambito-juridico.com.br/site/?n_link=revista_artigos_leitura\&artigo_id=13321>. Acesso em: 25 abr. 2015.

${ }^{19}$ CAMPOS, P. T. de. Cooperação jurídica internacional: carta rogatória e homologação de sentença estrangeira. In: Âmbito Jurídico, Rio Grande, XVI, n. 113, jun 2013. Disponível em: <http://www.ambito-juridico.com.br/site/?n_link=revista_artigos_leitura\&artigo_id=13321>. Acesso em: 25 abr. 2015.

20 MARCATO, A. C. Código de Processo Civil interpretado. São Paulo: Atlas, 2004. p. 519.

${ }^{21} \mathrm{O}$ poder jurisdicional do Estado limita-se a seu território e o juiz não pode determinar citação no Estado Estrangeiro. BAPTISTA, L. O.; HUCK, H. M.; CASELLA, P. B. (cord.). Direito e comércio internacional: tendências e perspectivas. Estudos em homenagem ao Prof. Irineu Strenger. São Paulo: LTr, 1994. p.152. 
MORAIS, Lindocastro Nogueira de; LIMA, Jhéssica Luara Alves de. Cooperação internacional em matéria de prova civil. Revista Eletrônica Direito e Política, Programa de Pós-Graduação Stricto Sensu em Ciência Jurídica da UNIVALI, Itajaí, v.11, n.3, 30 quadrimestre de 2016. Disponível em: www.univali.br/direitoepolitica - ISSN 1980-7791.

tais como citações, notificações, entre outros atos ${ }^{22}$. A carta rogatória é pois, o veículo de transmissão de qualquer pedido judicial ${ }^{23}$.

A cooperação jurídica internacional e seu avanço é o reflexo da preocupação dos países em concretizar o acesso à Justiça no âmbito das relações internacionais. A Carta Rogatória é um instituto tradicional que a cada dia é aperfeiçoado para melhor adaptar-se às necessidades atuais de cooperação mútua internacional em matéria de prova civil ${ }^{24}$. Assim sendo, importante o aperfeiçoamento desse instrumento para que possa ser ágil ${ }^{25}$ e, consequentemente, efetivo.

\subsection{HOMOLOGAÇÃO DE SENTENÇA ESTRANGEIRA}

A sentença prolatada por juiz ou tribunal estrangeiro terá eficácia somente após a sua homologação ${ }^{26}$. No Brasil, as normas para homologação de sentença estrangeira estão previstas na Constituição Federal, no Novo Código de Processo Civil, na Lei de Introdução às normas do Direito Brasileiro e no Regimento Interno do Supremo Tribunal Federal. A finalidade do processo homologatório é o reconhecimento da eficácia jurídica da sentença estrangeira perante a ordem jurídica de país diverso,

22 BRASIL. Ministério da Justiça. Plano Interno e Internacional. Manual de Cooperação Jurídica Internacional e Recuperação de Ativos. 2. ed. Brasília: 2009. p. 25.

23 BRASIL. Ministério da Justiça. Plano Interno e Internacional. Manual de Cooperação Jurídica Internacional e Recuperação de Ativos. 2. ed. Brasília: 2009. p. 38.

24 BRASIL. Ministério da Justiça. Plano Interno e Internacional. Manual de Cooperação Jurídica Internacional e Recuperação de Ativos. 2. ed. Brasília: 2009. p. 20.

25 No Brasil, vige o princípio da celeridade processual, conforme consagrado no art. 50, LXXVIII, que diz: a todos, no âmbito judicial e administrativo, são assegurados a razoável duração do processo e os meios que garantam a celeridade de sua tramitação. De acordo com Zanferdini (2003, p. 253), em parte da legislação alienígena, a garantia da duração razoável do processo está inserida na Constituição da Itália (art. 111), na Constituição portuguesa (art. 20), no Código de Processo Civil português (art. $2^{\circ}$ ), além do Bill of Rights americano ( $\left.n^{\circ} 6\right)$.

26 No Brasil, essa homologação é feita pelo Superior Tribunal de Justiça (STJ). De acordo com a Resolução no 9 do STJ, a homologação de sentença estrangeira é um processo que visa conferir eficácia a um ato judicial estrangeiro. Qualquer provimento, judicial ou não, proveniente de uma autoridade estrangeira só terá eficácia no Brasil após sua homologação pelo STJ. 
MORAIS, Lindocastro Nogueira de; LIMA, Jhéssica Luara Alves de. Cooperação internacional em matéria de prova civil. Revista Eletrônica Direito e Política, Programa de Pós-Graduação Stricto Sensu em Ciência Jurídica da UNIVALI, Itajaí, v.11, n.3, 30 quadrimestre de 2016. Disponível em: www.univali.br/direitoepolitica - ISSN 1980-7791.

sendo indiferente se as sentenças são declaratórias, constitutivas ou condenatórias ${ }^{27}$.

A homologação de sentença estrangeira e sua execução tem relação direta com a circulação internacional dos julgados, promovendo a eficácia da cooperação mútua entre os países e garantindo o funcionamento e a manutenção do sistema internacional e dos direitos conferidos pelos documentos internacionais ${ }^{28}$.

O pedido de homologação de sentença serve para o reconhecimento e a posterior execução de provimento jurisdicional de autoridade estrangeira ${ }^{29}$. Ele garante, ao menos em tese, a rapidez e a eficácia do trânsito de atos processuais e jurisdicionais para o cumprimento dessas medidas. Assim, ocorre a cooperação mútua entre os Estados para assegurar o pleno funcionamento da Justiça. A homologação de sentença se dá, no plano mundial, por meio de convenções internacionais, multilaterais, bilaterais ou oriundas de processos de integração entre os países ${ }^{30}$.

A homologação de sentenças estrangeiras serve para assegurar a boa convivência com a comunidade internacional, sendo essencial para que a sentença estrangeira possa ser executada no Estado que a recebeu e homologou ${ }^{31}$. Dessa forma, a

27 Segundo o art. 17 da Lei de Introdução às normas do Direito Brasileiro, e art. 216 do Regimento Interno do Supremo Tribunal Federal, não será homologada no Brasil a sentença que ofenda a soberania nacional, a ordem pública e os bons costumes.

28 BRASIL. Ministério da Justiça. Plano Interno e Internacional. Manual de Cooperação Jurídica Internacional e Recuperação de Ativos. 2. ed. Brasília: 2009.

${ }^{29}$ As possibilidades de recusa do julgamento são limitadas e estão em consonância com as regras de homologação de sentença estrangeira, portanto compatível com o direito interno do país membro. ARAÚJO, N.; VARGAS, D. A conferência da Haia de direito internacional privado: reaproximação do Brasil e análise das convenções processuais. Revista de Arbitragem e Mediação, vol.35/2012, Out/2012, DTR\2012\451121. p.189.

${ }^{30}$ ARAÚJO, N.; VARGAS, D. A conferência da Haia de direito internacional privado: reaproximação do Brasil e análise das convenções processuais. Revista de Arbitragem e Mediação, vol.35/2012, Out/2012, DTR\2012\451121. p.190.

31 Obviamente que essa homologação encontra limites como forma de proteger os interesses nacionais. No Brasil, o art. 17 da Lei de Introdução às normas de Direito Brasileiro (LINDB), estabelece limites a serem observados: "Art. 17. As leis, atos e sentenças de outro país, bem como quaisquer declarações de vontade, não terão eficácia no Brasil, quando ofenderem a soberania nacional, a ordem pública e os bons costumes". 
MORAIS, Lindocastro Nogueira de; LIMA, Jhéssica Luara Alves de. Cooperação internacional em matéria de prova civil. Revista Eletrônica Direito e Política, Programa de Pós-Graduação Stricto Sensu em Ciência Jurídica da UNIVALI, Itajaí, v.11, n.3, $3^{0}$ quadrimestre de 2016. Disponível em: www.univali.br/direitoepolitica - ISSN 1980-7791.

homologação de sentenças estrangeiras possui importância na cooperação entre os Estados, sendo uma das formas pelas quais essa cooperação se concretiza ${ }^{32}$.

\subsection{PEDIDO DE EXTRADIÇÃO}

A extradição é o mais antigo e tradicional instrumento de cooperação internacional recorrente ao longo da história. A entrega de uma pessoa acusada de ter cometido crime grave envolve diretamente os princípios da territorialidade e extraterritorialidade ${ }^{33}$. Trata-se do processo pelo qual um Estado entrega, mediante requerimento do Estado interessado, pessoa condenada ou indiciada no país requerente, cuja legislação é competente para julgá-la pelo crime que lhe é imputado ${ }^{34}$. O pedido de extradição acontece para que as pessoas condenadas possam cumprir sua pena no seu país. A extradição possui caráter humanitário, uma vez que permite ao indivíduo estar perto de sua família, facilitando sua reinserção no seio da sociedade ${ }^{35}$.

A extradição ocorre geralmente por meio de um tratado com o país requerente. Nem todos os países possuem esse tipo de tratado específico com todos os países ${ }^{36}$. Se entre os países há esse tratado específico, o pedido de extradição não comporta

\footnotetext{
32 REQUER, T. S. Homologação de Sentença Estrangeira e Carta Rogatória: uma análise sobre a jurisprudência do STJ. $2015 . \quad$ Disponível em: <http://www.migalhas.com.br/dePeso/16,MI215203, 71043Homologacao+de+Sentenca+Estrangeira+e+Carta+Rogatoria+uma+analise>. Acesso em: 20 mai. 2015.

33 Importante destacar que a extradição destina-se a julgar autores de ilícitos penais, não sendo, em tese, admitida para processos de natureza puramente administrativa, civil ou fiscal. DEL'OLMO, F. de S., KÄMPF, E. C. D. A extradição no direito Brasileiro. Rio de Janeiro: GZ Editora, 2011. p. 34.

${ }^{34}$ DEL'OLMO, F. de S., KÄMPF, E. C. D. A extradição no direito Brasileiro. Rio de Janeiro: GZ Editora, 2011. p. 34.

${ }^{35}$ BRASIL. Ministério da Justiça. Plano Interno e Internacional. Manual de Cooperação Jurídica Internacional e Recuperação de Ativos. 2. ed. Brasília: 2009. p. 16.
}

${ }^{36}$ No caso do Brasil, este não possui tratados específicos sobre extradição com todos os países. 
MORAIS, Lindocastro Nogueira de; LIMA, Jhéssica Luara Alves de. Cooperação internacional em matéria de prova civil. Revista Eletrônica Direito e Política, Programa de Pós-Graduação Stricto Sensu em Ciência Jurídica da UNIVALI, Itajaí, v.11, n.3, $3^{\circ}$ quadrimestre de 2016. Disponível em: www.univali.br/direitoepolitica - ISSN 1980-7791.

recusa infundada, uma vez que a existência de um tratado marca um compromisso entre os países. Todavia, quando da inexistência de tratado específico, a reciprocidade pode ser acolhida ou rejeitada ${ }^{37}$.

O pedido de extradição é mais um instrumento tradicional de cooperação internacional entre os Estados, o qual passou a ser subordinado às normas constitucionais do Estado requerido, objetivando firmar a soberania do país, diminuindo fronteiras geográficas, integrando regiões, facilitando e agilizando os processos em prol da segurança estatal e cidadania ${ }^{38}$.

\subsection{TRANSFERÊNCIA DE PESSOAS CONDENADAS}

A transferência de pessoas condenadas é uma forma de cooperação entre os Estados e possui cunho essencialmente humanitário, baseado no princípio da dignidade da pessoa humana ${ }^{39}$. Esse ato permite à pessoa condenada o cumprimento da pena no seu Estado de origem, visando facilitar sua reabilitação e posterior ressocialização. A transferência de pessoas condenadas faz parte do instituto de cooperação jurídica internacional, sendo cada vez mais comum a solicitação de cumprimento da pena em seu país de origem ${ }^{40}$.

37 MAZZUOLI, V. de O. Coletânea de direito internacional. Ed. ampliada. São Paulo: Editora Revista dos Tribunais, 2006. p. 742.

38 A legislação brasileira compreende a extradição como um ato essencialmente político, pois cabe ao Poder Executivo a decisão final sobre o pedido, restando ao Poder Judiciário apenas julgar se o pedido está de acordo com as formalidades exigidas. PINHEIRO, G. M.; MAIDANA, J. R. O processo de extradição no sistema brasileiro. 2013. Disponível em: <http://www.egov.ufsc.br/portal/conteudo/o-processo-de-extradi\%C3\%A7\%C3\%A3o-nosistema-brasileiro>. Acesso em: 20 mai. 2015.

${ }^{39}$ A dignidade da pessoa humana está consagrada na legislação brasileira, no art. 10, inciso III, da Constituição Federal como um dos fundamentos da República Federativa do Brasil.

40 JALES, L. C. P. Transferência de presos em cooperação jurídica internacional. Revista Jus Navigandi, Teresina, ano 19, n. 3955, 30 abr. 2014. Disponível em: < http://jus.com.br/artigos/27874/transferencia-de-presos-em-cooperacao-juridica-internacional> . Acesso em: 28 abr. 2015. 
MORAIS, Lindocastro Nogueira de; LIMA, Jhéssica Luara Alves de. Cooperação internacional em matéria de prova civil. Revista Eletrônica Direito e Política, Programa de Pós-Graduação Stricto Sensu em Ciência Jurídica da UNIVALI, Itajaí, v.11, n.3, 30 quadrimestre de 2016. Disponível em: www.univali.br/direitoepolitica - ISSN 1980-7791.

O Brasil possui tratados bilaterais ${ }^{41}$ e multilaterais firmados com diversos países, acerca da transferência de pessoas condenadas.

O Brasil promulgou o Tratado entre a República Federativa do Brasil e a República Portuguesa sobre a Transferência de Pessoas Condenadas, em 5 de setembro de 2001, por meio do Decreto no 5.767, de 2 de maio de 2006, o que o fizeram animados pelos laços de fraternidade, amizade e cooperação que presidem as relações entre ambos os países. Esses tratados são realizados pelo desejo de reforçar a cooperação judiciária mútua.

Os instrumentos tradicionais de cooperação jurídica internacional, todavia, tem cedido espaço para novos meios de colaboração entre os países, especialmente no que tange ao auxílio para a produção de provas.

\section{AUXÍLIO INTERNACIONAL DIRETO NA PRODUÇÃO DE PROVA}

A cooperação internacional em matéria de prova civil, atualmente se dá por meio de duas vias, quais sejam, a indireta, através da carta rogatória e homologação de sentença estrangeira, por exemplo, e direta, perfectibilizada no auxílio ou assistência direta $^{42}$. No Brasil, o auxílio internacional direto ${ }^{43}$ é a modalidade de cooperação jurídica internacional que não necessita do juízo de delibação do Superior Tribunal de Justiça, em razão de sua natureza administrativa, ou pelo fato de se buscar uma decisão judicial brasileira relativa a litígio, advinda de Estado estrangeiro ${ }^{44}$.

41 Dentre os tratados bilaterais firmados pelo Brasil em matéria de transferência de pessoas condenadas, tem-se: Argentina (Decreto 3.875/2001) Angola (Decreto 8.316/2014), Bolívia (Decreto 6.128/2007), Canadá (Decreto n. 2.547/1998), Chile (Decreto n. 3.002/1999), Espanha (Decreto n. 2.576/1998), Panamá (Decreto n. 8.050/2013), Paraguai (Decreto n. 4.443/2002), Peru (Decreto 5.931/2006), Países Baixos (Decreto 7.906/2013), Portugal (Decreto 5.767/2006), Reino Unido da Grã-Bretanha e Irlanda do Norte (Decreto n. 4.107/2002).

42 BARBOSA JÚNIOR, M. M. Cooperação jurídica internacional em matéria civil, tutelas de urgência e precedentes dos tribunais superiores. Revista Jus Navigandi, Teresina, ano 17, n. 3142, 7 fev. 2012. Disponível em: <http://jus.com.br/artigos/21036>. Acesso em: 03 jun. 2015.

${ }^{43}$ No sistema constitucional brasileiro, o tema de cooperação jurídica internacional foi tratado de forma esparsa e genérica.

44 NOTAS DE AULA. Cooperação jurídica internacional: carta rogatória e auxílio direto. Disponível em: <http://notasdeaula.org/dir10/direito_int_privado_25-05-12.html>. Acesso em: 03 abr. 2015. 
MORAIS, Lindocastro Nogueira de; LIMA, Jhéssica Luara Alves de. Cooperação internacional em matéria de prova civil. Revista Eletrônica Direito e Política, Programa de Pós-Graduação Stricto Sensu em Ciência Jurídica da UNIVALI, Itajaí, v.11, n.3, $3^{0}$ quadrimestre de 2016. Disponível em: www.univali.br/direitoepolitica - ISSN 1980-7791.

A redução das fronteiras, o aumento das relações entre os países, a expansão das negociações comerciais internacionais, o aumento da migração e dos crimes transnacionais, passaram a exigir novos métodos de cooperação jurídica internacional ${ }^{45}$.

Dessa forma, surgiu o chamado auxílio internacional direto ${ }^{46}$. 0 auxílio internacional direto na produção de prova facilita a interação de soluções para problemas estatais de difícil solução referente ao aparato judicial e administrativo de um determinado estado, necessitando recorrer ao auxílio de outras nações (art. 31). O auxílio internacional direto na produção de prova é uma ferramenta de cooperação jurídica que ganhou maior importância no Brasil em razão da promulgação do novo Código de Processo Civil que traz um capítulo especial dedicado a cooperação internacional. Nos termos do novo CPC brasileiro, o auxílio direto é cabível quando a medida não decorre diretamente de decisão de autoridade jurisdicional estrangeira a ser submetida a juízo de delibação no Brasil (art. 28) ${ }^{47}$.

É injustificável o receio de que o auxílio internacional ofenda o poder soberano dos países, pois o atendimento aos pedidos de cooperação estão condicionados à sua consonância com os preceitos da ordem pública e do interesse nacional dos Estados envolvidos $^{48}$. Isso se dá porque $\mathrm{o}$ atendimento aos pedidos de cooperação se condicionam à sua consonância aos preceitos da ordem pública e do interesse nacional.

\footnotetext{
45 TOFOLLI, J. A. D.; CESTARI, V. C. J. Mecanismos de Cooperação Jurídica Internacional no Brasil. Disponível em: <ile:///C:/Users/Cliente/Downloads/artigo_mecanismos_de_cooperacao_juridica_internacional_no_brasil.pdf>. Acesso em: 20 abr. 2015.

${ }^{46}$ O Auxílio Internacional Direto também é chamado de cooperação judiciária internacional stricto sensu.

47 Nos termos do novo Código de Processo Civil brasileiro, Art. 30. Além dos casos previstos em tratados de que o Brasil faz parte, o auxílio direto terá os seguintes objetos: I - obtenção e prestação de informações sobre o ordenamento jurídico e sobre processos administrativos ou jurisdicionais findos ou em curso; II - colheita de provas, salvo se a medida for adotada em processo, em curso no estrangeiro, de competência exclusiva de autoridade judiciária brasileira; III - qualquer outra medida judicial ou extrajudicial não proibida pela lei brasileira.
}

48 JALES, L. C. P. Transferência de presos em cooperação jurídica internacional. Revista Jus Navigandi, Teresina, ano 19, n. 3955, 30 abr. 2014. Disponível em: < http://jus.com.br/artigos/27874/transferencia-de-presos-em-cooperacao-juridica-internacional>. Acesso em: 28 abr. 2015. 
MORAIS, Lindocastro Nogueira de; LIMA, Jhéssica Luara Alves de. Cooperação internacional em matéria de prova civil. Revista Eletrônica Direito e Política, Programa de Pós-Graduação Stricto Sensu em Ciência Jurídica da UNIVALI, Itajaí, v.11, n.3, $3^{0}$ quadrimestre de 2016. Disponível em: www.univali.br/direitoepolitica - ISSN 1980-7791.

O auxílio internacional direto na produção de prova depende da manutenção da cooperação jurídica internacional entre os países. Essa cooperação, assim como outros mecanismos processuais para a garantia do devido processo legal, enfrenta dificuldades, especialmente no que respeito à elaboração de tratados internacionais que regulem, na forma devida, os procedimentos necessários a serem adotados entre os países membros.

Além disso, tem-se a dificuldade na exigibilidade do dever de cooperar. Como se não bastasse, o desconhecimento da temática constante do tratado por parte dos que operam o Direito dificulta o cumprimento deste. No caso, é preciso conhecimento dos tramites processuais em matéria de Direito Internacional, para que a cooperação entre os países surta o efeito almejado ${ }^{49}$.

Em matéria de cooperação jurídica internacional para fins de auxílio internacional direto na produção de prova, é fundamental o respeito à boa-fé50 . O magistrado que, em sede de primeiro, grau recebe o pedido de auxílio direto tem cognição plena para apreciá-lo, entretanto, deve estabelecer o contraditório para fins de ajudar no seu livre convencimento ${ }^{51}$.

Dentre as convenções internacionais que tratam de auxílio direto em matéria civil, tem-se a Convenção da Haia sobre os Aspectos Civis do Seqüestro Internacional de Crianças $^{52}$, concluída na cidade de Haia, em 25 de outubro de 1980. Além desta, tem-se a Convenção de Nova Iorque sobre a Prestação de Alimentos no Estrangeiro, a qual conta com o apoio da Organização das Nações Unidas (ONU) ${ }^{53}$.

49 TROTTA, S. B. Os limites da cooperação jurídica internacional em matéria penal. Revista Eletrônica da Faculdade de Direito PUCRS. Sistema Penal e Violência, Porto Alegre, v. 5, n. 1, p. 15-35, jan./jun., 2013.

50 TROTTA, S. B. Os limites da cooperação jurídica internacional em matéria penal. Revista Eletrônica da Faculdade de Direito PUCRS. Sistema Penal e Violência, Porto Alegre, v. 5, n. 1, p. 18, jan./jun., 2013.

51 TROTTA, S. B. Os limites da cooperação jurídica internacional em matéria penal. Revista Eletrônica da Faculdade de Direito PUCRS. Sistema Penal e Violência, Porto Alegre, v. 5, n. 1, p. 19, jan./jun., 2013.

52 O Governo brasileiro depositou o Instrumento de Adesão da referida Convenção em 19 de outubro de 1999, passando a mesma a entrar em vigor para o Brasil, em 1을 de janeiro de 2000, por meio do Decreto no 3.413, de 14 de abril de 2000.

${ }^{53}$ Essa convenção foi promulgada no Brasil por meio do Decreto no 56.826, de 02 de setembro de 1965. Além do Brasil, aderiram a esta Convenção os seguintes países: Alemanha, Alto Volta, 
MORAIS, Lindocastro Nogueira de; LIMA, Jhéssica Luara Alves de. Cooperação internacional em matéria de prova civil. Revista Eletrônica Direito e Política, Programa de Pós-Graduação Stricto Sensu em Ciência Jurídica da UNIVALI, Itajaí, v.11, n.3, 30 quadrimestre de 2016. Disponível em: www.univali.br/direitoepolitica - ISSN 1980-7791.

Tem-se, também, a Convenção da Haia sobre Direito Processual Civil ${ }^{54}$. No âmbito do Mercado Comum do Sul (Mercosul), tem-se o Protocolo de Las Leñas sobre Cooperação Civil, Comercial, Trabalhista e Administrativa ${ }^{55} 56$.

\section{COMPARTILHAMENTO INTERNACIONAL DE PROVA}

No sistema jurídico brasileiro, os acordos e convenções incorporados ao direito interno brasileiro adquirem força de lei. Assim, o compartilhamento de prova se mostra viável para a descoberta dos fatos e para fundamentar as decisões. O Ministério da Justiça anunciou a adesão do Brasil à Convenção de Haia sobre a obtenção de provas, promulgada na cidade holandesa em 1970 e ratificada por outros 57 países. O objetivo da Conferência é trabalhar pela unificação progressiva das regras de direito internacional, em que pessoas físicas e jurídicas possam beneficiar-se de um elevado grau de segurança jurídica ${ }^{57}$.

A cooperação internacional é essencial e depende do compartilhamento de provas no âmbito das relações entre os países. Dessa forma, com esse compartilhamento, é possível perceber o estreitamento das relações entre os países, por meio da intensificação da assinatura de tratados, convenções e protocolos, todos fundamentados no auxílio mútuo entre os Estados.

Assim, através do compartilhamento internacional de prova, viabiliza-se o intercâmbio de soluções para problemas estatais dos países que necessitam recorrer

Argélia, Argentina, Austria, Bélgica, Bolívia, Camboja, Ceilão, Chile, China, Colômbia, Cuba, Dinamarca, El Salvador, Equador, Espanha, Filipinas, Finlândia, França, Grécia, Guatemala, Haití, Hungria, Israel, Iugoslávia, Luxemburgo, Marrocos, México, Mônaco, Niger, Noruega e Países Baixos.

54 A Conferência da Haia de Direito Internacional Privado conta atualmente com 72 Estados Membros, sendo 71 Estados e a União Europeia. Esta convenção, de $1^{\circ}$ de março de1954, não foi promulgada pelo Brasil.

55 O Acordo entrou em vigor para o Brasil, no plano jurídico externo, em 8 de fevereiro de 2009 e no plano interno passou a vigorar com o decreto no 6.891 , de 2 de julho de 2009 .

56 TOFOLLI, J. A. D.; CESTARI, V. C. J. Mecanismos de Cooperação Jurídica Internacional no Brasil. Disponível em: <file://C:/Users/Cliente/Downloads/artigo_mecanismos_de_cooperacao_juridica_internacional_no_brasil.pdf>. Acesso em: 20 abr. 2015.

57 MIGALHAS. Adesão à Convenção de Haia facilitará produção de provas. Disponível em: < http://www.migalhas.com.br/Quentes/17,MI199181,31047-

Adesao+a+Convencao+de+Haia+facilitara+producao+de+provas>. Acesso em: 28 abr. 2015. 
MORAIS, Lindocastro Nogueira de; LIMA, Jhéssica Luara Alves de. Cooperação internacional em matéria de prova civil. Revista Eletrônica Direito e Política, Programa de Pós-Graduação Stricto Sensu em Ciência Jurídica da UNIVALI, Itajaí, v.11, n.3, $3^{0}$ quadrimestre de 2016. Disponível em: www.univali.br/direitoepolitica - ISSN 1980-7791.

ao auxílio de outros Estados para a resolução de um conflito ${ }^{58}$. Como exemplo de compartilhamento internacional de prova, tem-se a prova emprestada ${ }^{59}$.

\subsection{PROVA EMPRESTADA INTERNACIONAL}

O direito à prova integra o quadro de garantias das partes. É com a instrução processual, por meio da atividade probatória, que se possibilita chegar a verdade dos fatos, auxiliando no desenvolvimento da atividade jurisdicional ${ }^{60}$.

Prova emprestada, por sua vez, é a prova de um fato, produzida em um processo, seja por documentos, testemunhas, confissão, depoimento pessoal ou exame pericial, que é trasladada para outro processo, por meio de certidão extraída daquele. ${ }^{61}$ Ainda que a lei processual nada disponha a respeito dela, a doutrina majoritária afirma a possibilidade de sua admissibilidade quando preenchidos alguns requisitos, sempre respeitando o princípio da legalidade e devido processo legal ${ }^{62}$.

A prova emprestada é uma medida que viabiliza o aproveitamento de atividade probatória anteriormente realizada63. Ao aproveitar as provas obtidas em juízo

58 TOFFOLI DIAS, J. A.; JUNGER CESTARI, V. (Org). Manual de Cooperação Jurídica Internacional e Recuperação de Ativos, em matéria civil. 1.ed. Brasília: ed. Ministério da Justiça, 2008. P. 22.

59 Para a jurisprudência brasileira, a prova colhida em outro processo pode servir de elemento de convicção para o julgador, pois na chamada prova emprestada inclui-se entre os meios moralmente legítimos que o Código de Processo Civil no art. 332 declara hábeis para provar a verdade dos fatos. Referido artigo diz o seguinte: "Art. 332. Todos os meios legais, bem como os moralmente legítimos, ainda que não especificados neste Código, são hábeis para provar a verdade dos fatos, em que se funda a ação ou a defesa."

60 LEITE, R. Prova emprestada no processo penal: limites e admissibilidade segundo STF e STJ. Disponível em: < http://rodrigoleite2.jusbrasil.com.br/artigos/121938519/prova-emprestada-noprocesso-penal-limites-e-admissibilidade-segundo-stf-e-stj>. Acesso em: 01 jun. 2015.

61 DIDIER JR., F. Curso de Direito Processual Civil: Teoria geral do processo e processo de conhecimento. 6. ed. Salvador: JusPodivm, 2006, p.523.

62 LOPES, J. B. A Prova no Direito Processual Civil. 2. ed. São Paulo: RT, 2002, p.64.

63 A prova emprestada é uma prova atípica no direito brasileiro, visto que não está prevista no Código de Processo Civil. 
MORAIS, Lindocastro Nogueira de; LIMA, Jhéssica Luara Alves de. Cooperação internacional em matéria de prova civil. Revista Eletrônica Direito e Política, Programa de Pós-Graduação Stricto Sensu em Ciência Jurídica da UNIVALI, Itajaí, v.11, n.3, $3^{0}$ quadrimestre de 2016. Disponível em: www.univali.br/direitoepolitica - ISSN 1980-7791.

diverso, a prova emprestada gera economia processual, garantindo efetividade ao processo, ${ }^{64}$ uma vez que reduz o tempo de trâmite processual ${ }^{65}$.

Para que a prova emprestada seja aceita, necessário que sejam trasladadas todas as peças processuais referentes à prova que se pretende emprestar, para fins de verificação de sua legitimidade, consubstanciado na boa-fé que devem se basear as relações jurídicas. A prova emprestada possui a mesma eficácia probatória do país em que foi produzida, pois a visão de que seria uma prova com valor documental inferior não é mais aceita.

O peso da prova emprestada será conferido pelo julgador, motivado no seu livre convencimento como é feito no seu país. Mesmo assumindo a forma documental, a prova emprestada deve manter seu valor originário, garantindo assim a máxima efetividade ${ }^{66}$.

A admissibilidade da prova emprestada está condicionada a algumas restrições, como por exemplo, a parte contra quem a prova é produzida deverá ter participado do contraditório para a construção da prova; a existência de relação entre os fatos do processo em que a prova foi produzida e os fatos a serem provados; e que seja impossível ou difícil a reprodução da prova emprestada no processo em que se pretenda demonstrar a veracidade da alegação, ${ }^{67}$ pois caso fosse fácil a reprodução, não haveria sentido.

O que se verifica é que a admissibilidade da prova emprestada no processo civil depende da observância aos princípios do devido processo legal, contraditório, e outras garantias processuais ${ }^{68}$, devendo ser valoradas diante do caso concreto.

64 CAMBI, E. A Prova Civil: Admissibilidade e relevância. São Paulo: Revista dos Tribunais, 2006. p. 53.

65 A prova emprestada encontra amparo na garantia constitucional da duração razoável do processo. Essa garantia está prevista no art. 50, inciso LXXVIII, da Constituição Federal brasileira de 1988.

66 TALAMINI, E. Prova emprestada no processo civil e penal. Revista de Informação Legislativa, Brasília, n. 140, out/dez. 1998. p. 147.

${ }^{67}$ ANDRADE, R. M. I. Direito Probatório Civil Brasileiro. Pelotas: Educat, 2006. p. 112.

68 MARinoni, L. G.; ARenhart, S. C. Manual do Processo de Conhecimento. 5. ed. São Paulo, Revista dos Tribunais, 2006. p. 293. 
MORAIS, Lindocastro Nogueira de; LIMA, Jhéssica Luara Alves de. Cooperação internacional em matéria de prova civil. Revista Eletrônica Direito e Política, Programa de Pós-Graduação Stricto Sensu em Ciência Jurídica da UNIVALI, Itajaí, v.11, n.3, $3^{0}$ quadrimestre de 2016. Disponível em: www.univali.br/direitoepolitica - ISSN 1980-7791.

\section{GARANTIAS PROCESSUAIS NA COOPERAÇÃO INTERNACIONAL}

A cooperação jurídica internacional demanda a criação e implementação de garantias processuais, uma vez que se trata de medidas executórias a serem cumpridas em país diverso. Assim, garantias como o devido processo legal, com direito a ampla defesa e o contraditório, e igualdade de partes, são dispositivos que asseguram tanto a cooperação jurídica internacional, quanto a proteção ao princípio da soberania do país ${ }^{69}$. A existência de uma atuação jurisdicional cooperativa no plano internacional não representa a solução para todos os dilemas da sociedade moderna globalizada, mas é um meio de colaborar para a superação do abismo entre o mundo globalizado e o Estado-Nação, na busca de um Estado integrado e cooperativo no plano internacional que atenda aos anseios sociais ${ }^{70}$.

Para que a cooperação internacional seja eficaz, é preciso que as garantias processuais sejam respeitadas. De fato, o devido processo legal com direito a ampla defesa, contraditório e igualdade de partes, são garantias positivas nas normas constitucionais, entretanto, precisam ser postas em prática, para que, de fato, os sujeitos processuais possuam acesso a elas e consigam utilizá-las no plano internacional.

Importante noção é a da superação do legalismo positivista, que identifica no legislador a figura fundamental para o desenvolvimento do Direito, enquanto que o Juiz seria um mero reprodutor das leis por eles propostas e sancionadas ${ }^{71}$. A atuação do operador do Direito na aplicação das normas trata-se de uma evolução da hermenêutica jurídica, em que passou a reconhecer o papel criativo e normativo da

${ }^{69}$ CAMPOS, P. T. de. Cooperação jurídica internacional: carta rogatória e homologação de sentença estrangeira. In: Âmbito Jurídico, Rio Grande, XVI, n. 113, jun 2013. Disponível em: <http://www.ambito-juridico.com.br/site/?n_link=revista_artigos_leitura\&artigo_id=13321>. Acesso em 02 jun. 2015.

70 MIZUTA, A.; HENDGES, C. E. J. Cooperação judicial internacional no combate à subtração internacional de menores no Brasil e na Colômbia. Revista do Direito Público, Londrina, v.10, n.1, p.99-126, jan./abr.2015.

${ }^{71}$ FACCHINI NETO, E. O Judiciário no mundo contemporâneo. In: MOLINARO, C. A.; MILHORANZA, M. G.; PORTO, S. G. Constituição, jurisdição e processo. Porto Alegre: Notadez, 2007. p. 297. 
MORAIS, Lindocastro Nogueira de; LIMA, Jhéssica Luara Alves de. Cooperação internacional em matéria de prova civil. Revista Eletrônica Direito e Política, Programa de Pós-Graduação Stricto Sensu em Ciência Jurídica da UNIVALI, Itajaí, v.11, n.3, 30 quadrimestre de 2016. Disponível em: www.univali.br/direitoepolitica - ISSN 1980-7791.

atividade jurisdicional. Essa atividade passou a ser vista como função essencial para o desenvolvimento do Direito no caso concreto $^{72}$.

Percebe-se, pois, que a atividade legislativa não é o suficiente para assegurar o alcance ao Direito. É certo que os tratados e acordos internacionais são necessários para a cooperação jurídica entre os países, entretanto, o Poder Judiciário exerce papel fundamental para a efetivação das garantias processuais a que os sujeitos têm direito ${ }^{73}$.

Supostamente a soberania seria uma barreira às interferências externas, em razão da autonomia plena do Estado, dificultando a concretização dos direitos individuais, limitando à efetivação das garantias dos sujeitos processuais ${ }^{74}$. Todavia, os tratados internacionais trazem a previsão dessas garantias, que devem alcançar todos os cidadãos, indistintamente.

Uma dificuldade que se apresenta para a efetividade das garantias dos instrumentos processuais é que muitos Estados impõem reservas em determinadas matérias, dificultando o avanço da cooperação internacional ${ }^{75}$.

Dessa forma, garantias processuais mínimas devem ser asseguradas nos tratados, acordos e convenções internacionais, permitindo maior integração entre os Estados e a coleta de provas para fins de julgamento de um caso concreto.

\subsection{DEVIDO PROCESSO LEGAL}

72 DIDIER JUNIOR, F. Teoria do processo e teoria do direito: o neoprocessualismo. In: (Org.). Teoria do processo: panorama doutrinário mundial. Salvador: Jus Podivm, 2010. p. 259.

73 MIZUTA, A.; HENDGES, C. E. J. Cooperação judicial internacional no combate à subtração internacional de menores no Brasil e na Colômbia. Revista do Direito Público, Londrina, v.10, n.1, p.99-126, jan./abr.2015.

74 MIZUTA, A.; HENDGES, C. E. J. Cooperação judicial internacional no combate à subtração internacional de menores no Brasil e na Colômbia. Revista do Direito Público, Londrina, v.10, n.1, p.105, jan./abr.2015.

75 CARVALHO FILHO, A. Obtenção transnacional de prova em matéria civil e comercial: Análise da Convenção de Haia de 1970, da Convenção Interamericana de 1975 e do Regulamento (CE) n. ${ }^{\circ} \quad 1206 / 2001 . \quad$ Disponível em: <http://www.abdpc.org.br/abdpc/artigos/Obten\%C3\%A7\%C3\%A30\%20transnacional\%20de\%2 Oprova\%20em\%20mat\%C3\%A9ria\%20civil\%20ou\%20comercial\%20-\%20artigo.pdf>. Acesso em: 08 mai. 2015. 
MORAIS, Lindocastro Nogueira de; LIMA, Jhéssica Luara Alves de. Cooperação internacional em matéria de prova civil. Revista Eletrônica Direito e Política, Programa de Pós-Graduação Stricto Sensu em Ciência Jurídica da UNIVALI, Itajaí, v.11, n.3, $3^{0}$ quadrimestre de 2016. Disponível em: www.univali.br/direitoepolitica - ISSN 1980-7791.

O processo deve estar em conformidade com o Direito como um todo, tanto no plano nacional como internacional ${ }^{76}$. Ele possui o objetivo de reprimir os abusos do Estado, principalmente no plano processual. A reverência ao devido processo legal é uma inovação no plano internacional, sendo um princípio consagrado pela Declaração Universal dos Direitos do Homem e do Cidadão ${ }^{77}$.

O devido processo legal é uma forma de controle de conteúdo das decisões ${ }^{78}$ e que permite às partes se defenderem por meio de todos os meios de prova em direito admitidas $^{79}$. Trata-se de um direito fundamental que possui um conteúdo complexo, estando sua construção em progresso eterno. O texto normativo do devido processo legal foi incorporado aos tratados internacionais e faz parte de inúmeras constituições $^{80}$.

A cooperação jurídica internacional tem ligação com o devido processual legal, uma vez que esta é uma das garantias basilares para a manutenção da ordem, respeito e soberania dos países. O devido processo legal possui função integrativa dos princípios, pois dele emanam outras normas e direitos fundamentais ${ }^{81}$ e pode ser compreendido em duas dimensões: formal ou procedimental e substancial.

A dimensão formal ou procedimental é a mais conhecida. É o direito ao processo com a garantia do contraditório, duração razoável do processo, juiz natural, e outras garantias processuais. Já a dimensão substancial, desenvolvida nos Estados Unidos da América, diz-se que um processo devido não é apenas aquele em que se

${ }^{76}$ DIDIER JR., F. Curso de direito processual civil: introdução ao direito processual civil, parte geral e processo de conhecimento. v. 1. 17. ed. Salvador: Jus Podivm, 2015. p. 63.

77 Art. 10. Toda a pessoa tem direito, em plena igualdade, a que a sua causa seja equitativa e publicamente julgada por um tribunal independente e imparcial que decida dos seus direitos e obrigações ou das razões de qualquer acusação em matéria penal que contra ela seja deduzida.

78 PRAVATO, F. O Devido Processo Legal e a Bilateralidade da Ampla Defesa. Disponível em: <http://feliperangel58.jusbrasil.com.br/artigos/164525862/o-devido-processo-legal-e-abilateralidade-da-ampla-defesa>. Acesso em: 03 jun. 2015.

79 No Brasil, o devido processo legal constitui garantia da manutenção da ordem do Estado Democrático de Direito e da condução de suas relações internacionais.

80 DIDIER JR., F. Curso de direito processual civil: introdução ao direito processual civil, parte geral e processo de conhecimento. v. 1. 17. ed. Salvador: Jus Podivm, 2015. p. 63.

81 DIDIER JR., F. Curso de direito processual civil: introdução ao direito processual civil, parte geral e processo de conhecimento. v. 1. 17. ed. Salvador: Jus Podivm, 2015. p. 67. 
MORAIS, Lindocastro Nogueira de; LIMA, Jhéssica Luara Alves de. Cooperação internacional em matéria de prova civil. Revista Eletrônica Direito e Política, Programa de Pós-Graduação Stricto Sensu em Ciência Jurídica da UNIVALI, Itajaí, v.11, n.3, $3^{0}$ quadrimestre de 2016. Disponível em: www.univali.br/direitoepolitica - ISSN 1980-7791.

observam exigências formais, mas sim que gera decisões jurídicas substancialmente devidas $^{82}$.

Segundo a jurisprudência do Supremo Tribunal Federal brasileiro, devido processo substantivo pode significar desde a proibição de leis que se apresentem distorcidas, exigindo-se que estas sejam elaboradas em observância à justiça, dotadas de razoabilidade e racionalidade, possuindo nexo com a finalidade que ela perquire ${ }^{83}$. Importante essa coerência nas leis e decisões, visto que são necessárias para a cooperação mútua entre os países membros de determinado tratado ou acordo internacional.

De fato, o devido processo legal possui todo o aparato jurídico para a proteção dos sujeitos processuais, do processo, e da efetividade da decisão. No entanto, essas garantias no plano da cooperação jurídica internacional se mostram deficientes, uma vez que garante os direitos, todavia, não os efetiva diante da burocracia, distância entre os países, ausência de recursos financeiros, entre outros entraves.

Em que pesem a inserção do princípio da cooperação internacional no texto constitucional e a multiplicidade de tratados, não há entre os operadores do direito uma difusão ampla a respeito da prática da cooperação. Os mecanismos de cooperação se mostram limitados. Além disso, os entendimentos jurisprudenciais tendem a ser restritivos, ao que é devida uma discussão apurada entre os paradigmas da soberania e da cooperação frente aos princípios do reconhecimento recíproco, da solidariedade e da confiança ${ }^{84}$.

\subsubsection{CONTRADITÓRIO}

O princípio do contraditório pode ser decomposto em duas garantias: participação e possibilidade de influência na decisão. A garantia da participação é a dimensão

82 DIDIER JR., F. Curso de direito processual civil: introdução ao direito processual civil, parte geral e processo de conhecimento. v. 1. 17. ed. Salvador: Jus Podivm, 2015. p. 67-68.

83 MATTOS, S. L. W. de. Devido processo legal e proteção de direitos. Porto Alegre: Livraria do Advogado, 2009, p. 97.

84 ABADE, D. N. Direitos fundamentais na cooperação jurídica internacional: extradição, assistência jurídica, execução de sentença estrangeira e transferência de presos. São Paulo: Saraiva, 2013. 
MORAIS, Lindocastro Nogueira de; LIMA, Jhéssica Luara Alves de. Cooperação internacional em matéria de prova civil. Revista Eletrônica Direito e Política, Programa de Pós-Graduação Stricto Sensu em Ciência Jurídica da UNIVALI, Itajaí, v.11, n.3, $3^{0}$ quadrimestre de 2016. Disponível em: www.univali.br/direitoepolitica - ISSN 1980-7791.

formal do referido princípio. Trata-se da garantia de ser ouvido, de participar ativamente do processo, ser comunicado e falar no processo ${ }^{85}$.

Para exemplificar o contraditório, a convenção sobre o acesso internacional à Justiça, aprovada em 1980, e que entrou em vigor no plano internacional em 1988, objetiva que as partes estrangeiras, quando for necessário, tenham a devida assistência jurídica, o que deve ocorrer nas mesmas condições dos residentes ou nacionais, tanto em matéria cível, como comercial. Essa convenção não se preocupa com as regras internas dos países quanto ao acesso à Justiça, mas sim, cuida da equiparação da aplicação de normas para a assistência judiciária ${ }^{86}$.

A garantia do contraditório está explícita nas legislações de diversos países e presentes nos tratados internacionais de cooperação mútua, todavia, é preciso entender que apenas a legalidade ou a positivação dessa garantia, não é suficiente para alcançar os objetivos da cooperação jurídica internacional.

É preciso que haja efetividade no cumprimento das garantias contidas nesses tratados e acordos internacionais, pois o exercício da jurisdição, tal como conhecido classicamente, não mais atende às demandas dos jurisdicionados.

Os conflitos modernos ganharam novos contornos, visto que as relações jurídicas entre as pessoas não estão restritas apenas ao âmbito interno de uma nação, mas têm se deslocado no espaço, fazendo surgir a chamada sociedade global, com conflitos que ultrapassam as barreiras das fronteiras geográficas e, portanto, merecem maior atenção por parte dos Estados ${ }^{87}$.

Desse modo, o contraditório é uma garantia que deve ultrapassar as fronteiras politicamente estabelecidas.

85 DIDIER JR., F. Curso de direito processual civil: introdução ao direito processual civil, parte geral e processo de conhecimento. v. 1. 17. ed. Salvador: Jus Podivm, 2015. p. 78.

${ }^{86}$ ARAÚJO, N.; VARGAS, D. A conferência da Haia de direito internacional privado: reaproximação do Brasil e análise das convenções processuais. Revista de Arbitragem e Mediação, vol.35/2012, p.189, Out/2012, DTR\2012\451121.

87 MIZUTA, A.; HENDGES, C. E. J. Cooperação judicial internacional no combate à subtração internacional de menores no Brasil e na Colômbia. Revista do Direito Público, Londrina, v.10, n.1, p.99-126, jan./abr.2015. 
MORAIS, Lindocastro Nogueira de; LIMA, Jhéssica Luara Alves de. Cooperação internacional em matéria de prova civil. Revista Eletrônica Direito e Política, Programa de Pós-Graduação Stricto Sensu em Ciência Jurídica da UNIVALI, Itajaí, v.11, n.3, $3^{0}$ quadrimestre de 2016. Disponível em: www.univali.br/direitoepolitica - ISSN 1980-7791.

\subsubsection{AMPLA DEFESA}

As medidas executórias adotadas nos tratados e acordos internacionais que versam sobre cooperação jurídica, tem a ampla defesa como princípio implícito para a proteção ao princípio da soberania dos países ${ }^{88}$.

A ampla defesa possui forte conexão com o contraditório ${ }^{89}$, inclusive, correspondendo ao aspecto substancial desse princípio. O desenvolvimento da dimensão substancial do princípio do contraditório permite à doutrina afirmar que ampla defesa e contraditório se fundiram em um único direito fundamental ${ }^{90}$.

A troca de informações por meio da cópia parcial ou integral de documentos ou por intermédio de correspondências trocadas entre os sujeitos de um processo, além de outras provas advindas das novas tecnologias, representa um progresso quanto a efetividade da ampla defesa nos processos vinculados a cooperação internacional. 0 acesso às provas produzidas em outro país permite o efetivo exercício das garantias individuais de caráter processual ${ }^{91}$.

A ampla defesa é fundamental à justiça, está intimamente ligada ao exercício do poder, influenciando a esfera jurídica das pessoas, considerada pela doutrina como inerente à própria noção de processo ${ }^{92}$.

A ampla defesa, não pode ser vista de modo restrito, pois engloba todas as fases processuais, desde a fase de conhecimento até a fase recursal, sendo condição inafastável do devido processo legal. A cooperação recíproca entre os países, que se

${ }^{88}$ CAMPOS, P. T. de. Cooperação jurídica internacional: carta rogatória e homologação de sentença estrangeira. In: Âmbito Jurídico, Rio Grande, XVI, n. 113, jun. 2013. Disponível em: <http://www.ambito-juridico.com.br/site/?n_link=revista_artigos_leitura\&artigo_id=13321>. Acesso em: 25 abr. 2015.

${ }^{89}$ No Brasil, ampla defesa e contraditório estão previstos no mesmo dispositivo constitucional, qual seja, o art. 50, LV.

90 DIDIER JR., F. Curso de direito processual civil: introdução ao direito processual civil, parte geral e processo de conhecimento. v. 1. 17. ed. Salvador: Jus Podivm, 2015. p. 86.

${ }^{91}$ DIDIER JR., F. Curso de direito processual civil: introdução ao direito processual civil, parte geral e processo de conhecimento. v. 1. 17. ed. Salvador: Jus Podivm, 2015. p. 22.

92 CINTRA, A.C.A.; GRINOVER, A.P.; DINAMARCO, C. R. Teoria Geral do Processo. 4.ed. São Paulo: Malheiros, 2008. p. 61. 
MORAIS, Lindocastro Nogueira de; LIMA, Jhéssica Luara Alves de. Cooperação internacional em matéria de prova civil. Revista Eletrônica Direito e Política, Programa de Pós-Graduação Stricto Sensu em Ciência Jurídica da UNIVALI, Itajaí, v.11, n.3, $3^{0}$ quadrimestre de 2016. Disponível em: www.univali.br/direitoepolitica - ISSN 1980-7791.

fundamenta em tratados internacionais ou, na inexistência destes, na garantia de reciprocidade, deve observar sempre a garantia constitucional da ampla defesa. ${ }^{93}$

A ampla defesa deve ter plena incidência na tramitação dos pedidos de cooperação internacional em matéria de prova civil. É preciso assegurar à parte atingida o direito de exercer a ampla defesa antes de sofrer um mal irreparável, oportunizando-lhe tentar evitá-lo com os recursos processuais em direito cabíveis. Além do interesse dos Estados em interagir informações, está também o interesse dos indivíduos que podem ser afetados com o resultado da troca de informações entre os Estados ${ }^{94}$.

Embora a ampla defesa seja tema recorrente no âmbito da cooperação internacional em matéria de direito penal, ela é princípio que deve nortear o direito como um todo, seja penal, administrativo, civil, entre outros ramos jurídicos. A cada dia mais, a ampla defesa em sede de cooperação internacional em matéria de prova civil cresce para fins de garantir a todos o devido processo legal, a integração entre os Estados, para fins de manutenção da soberania dos países. As Autoridades Centrais vem desenvolvendo a missão de facilitar e acelerar a tramitação dos pedidos de auxílio internacional em matéria de prova civil, sempre respeitando a ampla defesa como uma das maiores conquistas mencionadas nos tratados internacionais ${ }^{95}$.

\subsubsection{IGUALDADE DE PARTES}

A igualdade de partes ou igualdade processual tem o propósito de tratar as partes com igualdade, observando os aspectos de imparcialidade do juiz em relação às partes; igualdade de acesso à justiça, sem discriminação; redução das desigualdades

93 MIZUTA, A.; HENDGES, C. E. J. Cooperação judicial internacional no combate à subtração internacional de menores no Brasil e na Colômbia. Revista do Direito Público, Londrina, v.10, n.1, p.99-126, jan./abr.2015.

94 BOTELHO, A; CAVALCANTE. Cooperação Jurídica Internacional em Matéria Penal no Brasil: as cartas rogatórias e o auxílio direto - controle dos atos pela parte atingida. Disponível em: <http://www.cabadvogados.com.br/shared/artigos_advogados/artigo_gv_final_site.pdf>. Acesso em: 08 jun. 2015. p. 09.

95 TROTTA, S. B. Os limites da cooperação jurídica internacional em matéria penal. Revista Eletrônica da Faculdade de Direito PUCRS. Sistema Penal e Violência, Porto Alegre, v. 5, n. 1, p. 15-35, jan./jun., 2013. p. 19. 
MORAIS, Lindocastro Nogueira de; LIMA, Jhéssica Luara Alves de. Cooperação internacional em matéria de prova civil. Revista Eletrônica Direito e Política, Programa de Pós-Graduação Stricto Sensu em Ciência Jurídica da UNIVALI, Itajaí, v.11, n.3, $3^{0}$ quadrimestre de 2016. Disponível em: www.univali.br/direitoepolitica - ISSN 1980-7791.

que dificultam o acesso à justiça, tais como a financeira, geográfica e de comunicação; e igualdade no acesso às informações para o exercício do contraditório e ampla defesa ${ }^{96}$.

As pessoas que fazem parte dos Estados membros dos tratados internacionais devem gozar das mesmas condições e prerrogativas conferidas aos nacionais do Estado, parte diversa em matéria de garantias processuais.. A igualdade de partes decorre do princípio da isonomia. Essa igualdade processual é inerente ao julgamento justo do processo, incorporando a noção de igualdade de armas ${ }^{97}$.

A igualdade de partes possui duas direções: primeiro dirige-se aos que se encontram nas mesmas posições no processo, tais como parte autora, parte ré e testemunhas, garantindo-Ihes idêntico tratamento processual; e, por segundo, dirige-se aos que estão em posições contrárias de parte autora e parte ré, assegurando a estes idênticas oportunidades de acesso à justiça, e impedindo que alguma parte seja beneficiada em detrimento da outra ${ }^{98}$.

De todos os aspectos que devem ser observados pelo princípio da igualdade de partes, chama atenção a redução das desigualdades que dificultam o acesso à justiça, tais como a financeira, geográfica e de comunicação. ${ }^{99} \mathrm{Na}$ teoria, o direito está garantido, todavia, na prática a realidade se mostra diferente em razão da burocracia.

Dentre os deveres morais dos Estados, o principal dever é o de assistência mútua, a qual se manifesta de diversas formas, como por exemplo: abrigo concedido por um Estado, em seus portos, a navios estrangeiros que procuram refúgio; os socorros marítimos em caso de naufrágio, incêndio a bordo, ou qualquer outro sinistro; a adoção de medidas sanitárias, que impeçam a propagação de enfermidades; a

96 DIDIER JR., F. Curso de direito processual civil: introdução ao direito processual civil, parte geral e processo de conhecimento. v. 1. 17. ed. Salvador: Jus Podivm, 2015. p. 97.

97 WASEK-WIADEREC, M. The principle of "equality of arms" in criminal procedure under Article 6 of the European Convention on Human Rights and its functions in criminal justice of selected European countries - A comparative view. Belgium: Leuven University Press, 2000. p. 27.

98 Fernandes, A. S. Processo Penal Constitucional. São Paulo: RT, 2007, p. 50.

99 Visando a concretização dos direitos das partes, a II Convenção Relativa ao Processo Civil (Adoptada na 7a Sessão - Haia, 01.03.1954), estabelece que as notificações não poderão dar lugar a reembolso de taxas ou custas de qualquer natureza (art. $7^{\circ}$ ). 
MORAIS, Lindocastro Nogueira de; LIMA, Jhéssica Luara Alves de. Cooperação internacional em matéria de prova civil. Revista Eletrônica Direito e Política, Programa de Pós-Graduação Stricto Sensu em Ciência Jurídica da UNIVALI, Itajaí, v.11, n.3, $3^{0}$ quadrimestre de 2016. Disponível em: www.univali.br/direitoepolitica - ISSN 1980-7791.

assistência e cooperação para a administração da justiça ${ }^{100}$. Quanto ao dever de assistência e cooperação para a administração da justiça em matéria de prova civil, tem-se que a igualdade de partes, juntamente como outras garantias processuais, deve servir para o bom andamento dessa cooperação, a qual é vista como um ideal a ser alcançado pelos países do globo ${ }^{101}$.

O Estado, para a realização de sua função social de pacificador, apenas alcançará seu intuito de proporcionar a completa proteção jurisdicional quando possuir meios que viabilizem o intercâmbio de atos processuais para além dos limites geográficos. Por sua vez, a ausência de cooperação internacional em matéria de prova civil poderá significar a ineficácia do poder jurisdicional.

\section{CONSIDERAÇÕES FINAIS}

As regras jurídicas, sistema de um país, quando construídas em conjunto por vários países, fortalecem as relações entre eles, garantindo direitos e deveres para os cidadãos. ${ }^{102}$ Dessa forma, o Estado, para atingir suas finalidades constitucionais, muitas vezes, precisa agir em operação conjunta, chamada de cooperação.

Verificou-se, pois, que a cooperação internacional em matéria de prova civil é imprescindível, devendo os países se adequarem às inovações do direito internacional contemporâneo. Para tanto, não se pode ignorar os instrumentos de cooperação, os quais tem o propósito de diminuir as distâncias entre os sistemas jurídicos, agilizando os procedimentos judiciais e administrativos. Instrumentos de cooperação tradicionais, presentes em convenções internacionais como a de Haia, tem cedido espaço para novos meios de integração mútua entre os países para fins de colaboração processual em matéria de prova civil.

Todos os países deveriam manter um relacionamento cooperativo entre si, no intuito de encontrar soluções para os problemas comuns entre eles, ou que pretendam

\footnotetext{
100 ACIOLY, H. Tratado de Direito Internacional Público. vol. I. São Paulo: Quartier Latin, 2009, pp. 314-315.

101 No dia 9 de abril de 2014, o Brasil aderiu à Convenção de Haia sobre Provas.

102 PONTES DE MIRANDA, F. C. Comentários à Constituição de 1967. vol. I, arts. 10 - 70. São Paulo : Editora Revista dos Tribunais, 1967, p. 39.
} 
MORAIS, Lindocastro Nogueira de; LIMA, Jhéssica Luara Alves de. Cooperação internacional em matéria de prova civil. Revista Eletrônica Direito e Política, Programa de Pós-Graduação Stricto Sensu em Ciência Jurídica da UNIVALI, Itajaí, v.11, n.3, 30 quadrimestre de 2016. Disponível em: www.univali.br/direitoepolitica - ISSN 1980-7791.

evitar. A cooperação internacional deve servir para o progresso da humanidade, em busca de uma integração econômica, política, social e cultural. A cooperação internacional é uma ferramenta que deve ser desenvolvida para o fortalecimento de culturas e valores humanitários das nações. ${ }^{103}$

É preciso, pois, que essa cooperação internacional seja eficaz não só para a garantia de obtenção de provas em matéria civil entre os países, mas para que os direitos processuais e individuais sejam respeitados pelos Estados.

\section{REFERÊNCIAS DAS FONTES CITADAS}

ABADE, Denise Neves. Direitos fundamentais na cooperação jurídica internacional: extradição, assistência jurídica, execução de sentença estrangeira e transferência de presos. São Paulo: Saraiva, 2013.

ACIOLY, Hildebrando. Tratado de Direito Internacional Público. vol. I. São Paulo: Quartier Latin, 2009.

ANDRADE, Rita Marasco Ippolito. Direito Probatório Civil Brasileiro. Pelotas: Educat, 2006.

ARAÚJO, Nadia de; GAMA JUNIOR, Lauro. Sentenças estrangeiras e cartas rogatórias: novas perspectivas da cooperação internacional. Disponível na Internet: <https://fichasmarra.wordpress.com/2011/01/29/sentencas-estrangeiras-e-cartasrogatorias-novas-perspectivas-da-cooperacao-internacional/>. Acesso em 05 jun. 2015.

ARAÚJO, Nadia de; VARGAS, Daniela. A conferência da Haia de direito internacional privado: reaproximação do Brasil e análise das convenções processuais. Revista de Arbitragem e Mediação, vol.35/2012, p.189, Out/2012, DTR\2012\451121.

BAPTISTA, Luiz Olavo; HUCK, Hermes Marcelo; CASELLA, Paulo Borba. (coord.). Direito e comércio internacional: tendências e perspectivas. Estudos em homenagem ao Prof. Irineu Strenger. São Paulo: LTr, 1994.

BARBOSA JÚNIOR, Márcio Mateus. Cooperação jurídica internacional em matéria civil, tutelas de urgência e precedentes dos tribunais superiores. Revista Jus Navigandi, Teresina, ano 17, n. 3142, 7 fev. 2012. Disponível em: <http://jus.com.br/artigos/21036>. Acesso em: 03 jun. 2015.

BOTELHO, Arruda; CAVALCANTI. Cooperação Jurídica Internacional em Matéria Penal no Brasil: as cartas rogatórias e o auxílio direto - controle dos atos pela

\footnotetext{
103 VALE, H. E. G. Princípio da cooperação internacional. Revista Jus Navigandi, Teresina, ano 19, n. 3864, 29 jan. 2014. Disponível em: <http://jus.com.br/artigos/26542>. Acesso em: 05 jun. 2015.
} 
MORAIS, Lindocastro Nogueira de; LIMA, Jhéssica Luara Alves de. Cooperação internacional em matéria de prova civil. Revista Eletrônica Direito e Política, Programa de Pós-Graduação Stricto Sensu em Ciência Jurídica da UNIVALI, Itajaí, v.11, n.3, $3^{0}$ quadrimestre de 2016. Disponível em: www.univali.br/direitoepolitica - ISSN 1980-7791.

parte atingida. Disponível em: <http://www.cabadvogados.com.br/shared/artigos_advogados/artigo_gv_final_site. pdf>. Acesso em: 08 jun. 2015.

BRASIL. Constituição (1988). Constituição da República Federativa do Brasil. Brasília, DF: Senado Federal, 1988.

. Lei no 5.869, de 11 de janeiro de 1973. Institui o Código de Processo Civil. Brasília: Senado Federal, 1973. Diário Oficial da República Federativa do Brasil, Brasília, DF, 11 jan. 1973, Seção 1.

- Lei no 13.105, de 16 de março de 2015. Código de Processo Civil. Brasília: Senado Federal, 2015. Diário Oficial da República Federativa do Brasil, Brasília, DF, 16 mar. 2015, Seção 1.

Ministério da Justiça. Plano Interno e Internacional. Manual de Cooperação Jurídica Internacional e Recuperação de Ativos. 2. ed. Brasília: 2009.

CAMPOS, Patrícia Toledo de. Cooperação jurídica internacional: carta rogatória e homologação de sentença estrangeira. In: Âmbito Jurídico, Rio Grande, XVI, n. 113, jun. 2013. Disponível em: <http://www.ambitojuridico.com.br/site/?n_link=revista_artigos_leitura\&artigo_id=13321>. Acesso em: 25 abr. 2015.

CARVALHO FILHO, Antônio. Obtenção transnacional de prova em matéria civil e comercial: Análise da Convenção de Haia de 1970, da Convenção Interamericana de 1975 e do Regulamento (CE) n. ${ }^{\circ}$ 1206/2001. Disponível em: <http://www.abdpc.org.br/abdpc/artigos/Obten\%C3\%A7\%C3\%A30\%20transnacion al\%20de\%20prova\%20em\%20mat\%C3\%A9ria\%20civil\%20ou\%20comercial\%20\%20artigo.pdf>. Acesso em: 08 mai. 2015.

CINTRA, Antonio Carlos Araujo; GRINOVER, Ada Pelegrini; DINAMARCO, Cândido Rangel. Teoria Geral do Processo. 4.ed. São Paulo: Malheiros, 2008.

DEL'OLMO, Florisbal de Souza; KÄMPF, Elisa Cerioli Del'olmo. A extradição no direito Brasileiro. Rio de Janeiro: GZ Editora, 2011.

DIDIER JR., Fredie. Curso de direito processual civil: introdução ao direito processual civil, parte geral e processo de conhecimento. v. 1. 17. ed. Salvador: Jus Podivm, 2015.

. Curso de Direito Processual Civil: Teoria geral do processo e processo de conhecimento. 6. ed. Salvador: Jus Podivm, 2006.

EUROPA. Sínteses de Legislações da União Européia. Cooperação Judiciária em Matéria Civil. Disponível em: $<$ http://europa.eu/legislation_summaries/justice_freedom_security/judicial_cooperat ion_in_civil_matters/index_pt.htm>. Acesso em: 28 abr. 2015.

FACCHINI NETO, Eugênio. O Judiciário no mundo contemporâneo. In: MOLINARO, C. A.; MILHORANZA, M. G.; PORTO, S. G. Constituição, jurisdição e processo. Porto Alegre: Notadez, 2007. 
MORAIS, Lindocastro Nogueira de; LIMA, Jhéssica Luara Alves de. Cooperação internacional em matéria de prova civil. Revista Eletrônica Direito e Política, Programa de Pós-Graduação Stricto Sensu em Ciência Jurídica da UNIVALI, Itajaí, v.11, n.3, 30 quadrimestre de 2016. Disponível em: www.univali.br/direitoepolitica - ISSN 1980-7791.

FERNANDES, Antonio Scarance. Processo Penal Constitucional. São Paulo: RT, 2007, p. 50.

FRANÇA, Rafael Francisco. Inquérito policial e exercício de defesa. Jus Navigandi, Teresina, ano 13, n. 1900, 13 set. 2008. Disponível em: <http://jus.com.br/artigos/11719/inquerito-policial-e-exercicio-de-defesa/2>. Acesso em: 18 jun. 2015.

GONZÁLEZ, Santiago Álvarez; REMACHA Y TEJADA, José Ramón. (Org.) Cooperación Jurídica Internacional. Colección Escuela Diplomática, n. 5. Madri, Boletin Oficial del Estado, 2001.

YODA, Ana Jamily Veneroso. As organizações internacionais e o poder de celebrar tratados. Disponível em: <http://www.planalto.gov.br/ccivil_03/revista/Rev_75/artigos/PDF/AnaVeneroso_Re v75.pdf>. Acesso em: 28 abr. 2015.

JALES, Lycia Cibely Porto. Transferência de presos em cooperação jurídica internacional. Revista Jus Navigandi, Teresina, ano 19, n. 3955, 30 abr. 2014. Disponível em: < http://jus.com.br/artigos/27874/transferencia-de-presos-emcooperacao-juridica-internacional>. Acesso em: 28 abr. 2015.

LOPES, João Batista. A Prova no Direito Processual Civil. 2. ed. São Paulo: RT, 2002.

MARCATO, Antonio Carlos. Código de Processo Civil interpretado. São Paulo: Atlas, 2004.

MARINONI, Luis Guilherme; ARENHART, Sergio Cruz. Manual do Processo de Conhecimento. 5. ed. São Paulo, Revista dos Tribunais, 2006.

MAZZUOLI, Valério de Oliveira. Coletânea de direito internacional. Ed. ampliada. São Paulo: Editora Revista dos Tribunais, 2006.

MCLEAN, David. International Co-operation in Civil and Criminal Matters. Oxford: Oxford University Press, 2002.

MINISTÉRIO DA JUSTIÇA. Cartilha Cooperação Jurídica Internacional em Matéria Civil. 2012. Disponível em: <http://www.tjsp.jus.br/download/corregedoria/cartasrogatorias/documentos/cartilh aexpedcrcivel.pdf>. Acesso em: 28 abr. 2015.

MIZUTA, Alessandra; HENDGES, Carla Evelise Justino. Cooperação judicial internacional no combate à subtração internacional de menores no Brasil e na Colômbia. Revista do Direito Público, Londrina, v.10, n.1, p.99-126, jan./abr.2015.

PINHEIRO, Giulia Manccini; MAIDANA, Javier Rodrigo. O processo de extradição no sistema brasileiro. 2013. Disponível em: <http://www.egov.ufsc.br/portal/conteudo/o-processo-deextradi\%C3\%A7\%C3\%A3o-no-sistema-brasileiro>. Acesso em: 20 mai. 2015.

PONTES DE MIRANDA, Francisco Cavalcanti. Comentários à Constituição de 1967. vol. I, arts. $1^{0}$ - 70. São Paulo : Editora Revista dos Tribunais, 1967. 
MORAIS, Lindocastro Nogueira de; LIMA, Jhéssica Luara Alves de. Cooperação internacional em matéria de prova civil. Revista Eletrônica Direito e Política, Programa de Pós-Graduação Stricto Sensu em Ciência Jurídica da UNIVALI, Itajaí, v.11, n.3, 30 quadrimestre de 2016. Disponível em: www.univali.br/direitoepolitica - ISSN 1980-7791.

PRAVATO, Felipe. O Devido Processo Legal e a Bilateralidade da Ampla Defesa. Disponível em: <http://feliperangel58.jusbrasil.com.br/artigos/164525862/o-devidoprocesso-legal-e-a-bilateralidade-da-ampla-defesa>. Acesso em: 03 jun. 2015.

REQUER, Taísa Silva. Homologação de Sentença Estrangeira e Carta Rogatória: uma análise sobre a jurisprudência do STJ. Disponível em: <http://www.migalhas.com.br/dePeso/16,MI215203,71043-

Homologacao+de+Sentenca+Estrangeira+e+Carta+Rogatoria+uma+analise $>$.

Acesso em: 20 mai. 2015.

TALAMINI, Eduardo. Prova emprestada no processo civil e penal. Revista de Informação Legislativa, Brasília, n. 140, PP. 145-162, out/dez. 1998.

TOFFOLI DIAS, José Antonio; JUNGER CESTARI, Virgínia Charpinel (Org). Manual de Cooperação Jurídica Internacional e Recuperação de Ativos, em matéria civil. 1.ed. Brasília: ed. Ministério da Justiça, 2008. 412p.

TROTTA, Sandro Brescovit. Os limites da cooperação jurídica internacional em matéria penal. Revista Eletrônica da Faculdade de Direito PUCRS, Sistema Penal e Violência, Porto Alegre, v. 5, n. 1, p. 15-35, jan./jun., 2013.

VALE, Horácio Eduardo Gomes. Princípio da cooperação internacional. Revista Jus Navigandi, Teresina, ano 19, n. 3864, 29 jan. $2014 . \quad$ Disponível em: <http://jus.com.br/artigos/26542>. Acesso em: 05 jun. 2015.

WASEK-WIADEREC, Malgorzata. The principle of "equality of arms" in criminal procedure under Article 6 of the European Convention on Human Rights and its functions in criminal justice of selected European countries - A comparative view. Belgium: Leuven University Press, 2000.

ZANFERDINI, Flávia de Almeida Montingelli. A crise da Justiça e do Processo e a Garantia do Prazo Razoável. Revista de Processo, São Paulo, n. 112, p. 240-262, out./dez., 2003.

Submetido em: maio/2016

Aprovado em: setembro/2016 